Supremasi Hukum : Jurnal Penelitian Hukum

p-ISSN: 1693-766X ; e-ISSN: 2579-4663, Vol. 28, No. 2, Agustus 2019, 123-134

\title{
UPAYA PEMERINTAH DAERAH MENGATASI KERUSAKAN LINGKUNGAN AKIBAT ALIH FUNGSI LAHAN BERDASARKAN KONSEP NEGARA KESEJAHTERAAN
}

\author{
Dinda Riskanita \\ Fakultas Hukum Universitas Muhammadiyah Yogyakarta \\ driskanita@gmail.com \\ Yeni Widowaty \\ Fakultas Hukum Universitas Muhammadiyah Yogyakarta \\ yeniwidowaty@umy.ac.id
}

\begin{abstract}
The purpose of this research is to find out and analyze the problem of land-use change impacts on environmental damage, and the efforts of local governments to overcome environmental damage based on the concept of the welfare state. The research method used is empirical research, which consists of primary data and secondary data. The research approach used is the legislative approach and the sociological approach. The results of the study of the two problems that the author examines are (1) that the impacts arising from environmental damage, namely landslides, lack of clean water, difficulty in reforestation, and loss of land characteristics, (2) the efforts of local governments in dealing with environmental damage is to do spatial planning based on statutory regulations in accordance with the Welfare State Concept.
\end{abstract}

Keywords: Damage; Environment; Government; Non-function; Welfare-State;

\begin{abstract}
Abstrak
Tujuan penelitian untuk mengetahui dan menganalisis persoalan tentang dampak alih fungsi lahan yang berakibat pada kerusakan lingkungan, dan upaya pemerintah daerah mengatasi kerusakan lingkungan berdasarkan konsep negara kesejahteraan. Metode penelitian yang digunakan adalah penelitian empiris, yang terdiri dari data primer dan data sekunder. Pendekatan penelitian yang digunakan adalah pendekatan perundang-undangan dan pendekatan sosiologis. Hasil penelitian dari dua permasalah yang penulis teliti adalah (1) bahwa dampak yang timbul dari kerusakan lingkungan, yaitu bencana longsor, minimnya air bersih, sulitnya melakukan reboisasi, dan hilangnya karakteristik lahan, (2) upaya pemerintah daerah dalam mengatasi kerusakan lingkungan tersebut adalah melakukan perencanaan tata ruang berdasarkan peraturan perundang-undangan sesuai dengan Konsep Negara Kesejahteraan.
\end{abstract}

Kata Kunci: Kerusakan; Lingkungan; Pemerintah; Alih-fungsi; Negara-Kesejahteraan;

\section{PENDAHULUAN}

Lingkungan merupakan suatu wadah untuk saling berinteraksinya makhluk

Dinda Riskanita, Upaya Pemerintah Daerah Mengatasi Kerusakan Lingkungan Akibat Alih Fungsi Lahan Berdasarkan Konsep Negara Kesejahteraan. 
Supremasi Hukum : Jurnal Penelitian Hukum

p-ISSN: 1693-766X ; e-ISSN: 2579-4663, Vol. 28, No. 2, Agustus 2019, 123-134

hidup yang berada didalamnya untuk membentuk suatu jaringan kehidupan. ${ }^{1}$ Dalam pengelolaan lingkungan, dibutuhkan prinsip berkelanjutan demi kelestarian lingkungan. Pengelolaan lingkungan yang baik menjadi wujud usaha pembangunan jangka panjang untuk kesejahteraan hidup.

Kesejahteraan hidup terdiri dari dua aspek, yaitu aspek lahiriah dan batiniah. ${ }^{2}$ Rangkaian program pembangunan jangka panjang berbasis lingkungan yang dilaksanakan oleh pemerintah juga mengutamakan pengelolaan tata ruang sebagai acuan untuk penggunaan lahan sesuai dengan pemanfaatan ruang sebagaimana hal ini sesuai dengan Pasal 1 angka 5 Undang-Undang Nomor 26 Tahun 2007 tentang Penataan Ruang. Pengelolaan lingkungan hidup yang tidak mengacu pada pengelolaan tata ruang dapat mengakibatkan kerusakan pada lingkungan, yang berdampak pada keseimbangan ekosistem.

Penyebab rusaknya lingkungan yang meliputi aspek daratan, laut dan udara secara garis besar disebabkan oleh dua faktor, yaitu faktor alam dan faktor manusia. ${ }^{3}$ Sedangkan kerusakan lingkungan yang disebabkan karena faktor manusia mempunyai dampak lebih kronis dan bersifat jangka panjang, serta dampaknya dapat secara langsung maupun tidak langsung. Contoh kerusakan lingkungan khususnya pada aspek daratan akibat ulah manusia yang paling banyak adalah penebangan hutan secara ilegal atau pembakaran hutan yang bertujuan untuk pembukaan lahan.

Hal ini pun sudah terbukti dengan adanya penelitian yang berjudul "Kerusakan lingkungan akibat alih fungsi lahan perbukitan menjadi lahan perkebunan di Kabupaten Ponorogo (Studi Kebijakan Formulasi Hukum)". ${ }^{4}$ Bahwa dalam tesis tersebut fakta yang diperoleh adalah lahan yang telah dikonversi tersebut memberikan dampak kerusakan lingkungan yang cukup besar. Hal yang terjadi adalah terjadinya longsor di kawasan lereng perbukitan yang ditanami dengan tanaman jahe (jenis tanaman berakar serabut), dengan luasan longsor 12, 2 hektar dengan volume 80 ribu kubik pada Januari 2018, menyebabkan sekitar 28 rumah penduduk terkena dampak, dikarenakan intensitas curah hujan deras tinggi yang terus mengguyur, maka longsor tidak hanya terjadi satu kali tapi terjadi beberapa kali longsor susulan. Ini disebabkan karena jenis tanah di

1 Netty Dahlah Uar, Sigit Heru Murti dan Suwarno Hadisusanto, Kerusakan Lingkungan Akibat Aktivitas Manusia pada Ekosistem Terumbu Karang, Jurnal MGI, ISSN 0215-1790, Vol 30 No 1, 2016, p. 89.

2 Faisal Akbar, Dimensi Hukum dalam Pemerintahan Daerah, Medan: Pustaka Bangsa Press, Cet. 1, 2003, hlm. 43.

3 Yosef Anata Christie, La Sina dan Rika Erawaty, Dampak Kerusakan Lingkungan Akibat Aktivitas Pembangunan Perumahan (Studi Kasus di Perumahan Palaran City oleh PT Kusuma Hady Property), Jurnal Beraja Niti, ISSN 2337-4608, Vol 2 No 11, 2013, p. 6.

4 Dinda Riskanita, Tesis: "Kerusakan Lingkungan Akibat Alih Fungsi Lahan Perbukitan Menjadi Lahan Perkebunan di Kabupaten Ponorogo (Studi Kebijakan Formulasi Hukum)", Yogyakarta, UMY, 2019, hlm. 10

Dinda Riskanita, Upaya Pemerintah Daerah Mengatasi Kerusakan Lingkungan Akibat Alih Fungsi Lahan Berdasarkan Konsep Negara Kesejahteraan. 
Supremasi Hukum : Jurnal Penelitian Hukum

p-ISSN: 1693-766X ; e-ISSN: 2579-4663, Vol. 28, No. 2, Agustus 2019, 123-134

lereng perbukitan yang tidak cocok jika ditanami dengan jahe karena jenis batuan itu memiliki sifat lepas-lepas yang sangat mudah terjadinya longsor. ${ }^{5}$

Adapun dampak dari terjadinya longsor akibat dari alih fungsi lahan tersebut adalah memburuknya sanitasi air bersih ke beberapa desa karena aliran air bersih langsung terputus saat terjadi longsor, 2 korban meninggal telah ditemukan, sedangkan 28 korban masih hilang. Sebanyak 300 jiwa mengungsi di rumah kepala desa dan menumpang sanak saudara terdekat yang aman dari longsor serta 35 rumah rusak terendam longsor. ${ }^{6}$

Oleh karena itu dalam penulisan ini penulis akan membahas terkait dampak kerusakan lingkungan akibat alih fungsi lahan perbukitan menjadi lahan perkebunan, dan upaya pemerintah daerah dalam mengatasi kerusakan lingkungan berdasarkan Konsep Negara Kesejahteraan. Kemudian tentunya penulisan ini bertujuan untuk mengetahui dan menganalisis terkait dampak kerusakan lingkungan yang ditimbulkan akibat alih fungsi lahan dan terkait upaya pemerintah daerah dalam mengatasi kerusakan lingkungan berdasarkan Konsep Negara Kesejahteraan.

\section{METODE PENELITIAN}

Metode penelitian yang digunakan dalam penelitian ini adalah penelitian empiris, dimana dalam penelitian empiris lebih menekankan pada gejala-gejala dan akibat yang terjadi berdasarkan di lapangan, atau dalam arti lain penelitian ini menggunakan metode observasi sebagai data primer untuk melihat bagaimana berjalannya hukum (law in action). Hal ini bertujuan untuk mendapatkan data yang akurat dalam mengolah data, yang kemudian dianalisis dengan data sekunder berupa buku, referensi artikel. Pendekatan dalam penelitian ini menggunakan pendekatan perundang-undangan dan pendekatan sosiologis. Pendekatan yang mengkaji peraturan perundang-undangan yang terkait, berbagai literatur dan referensi lainnya yang berkaitan dengan gejala sosial yang terjadi di masyarakat.

\section{HASIL DAN PEMBAHASAN}

\section{Konsep Negara Kesejahteraan (Welfare State)}

Negara modern yang berkembang seperti saat ini adalah personifikasi/bagian dari tata hukum. ${ }^{7} \mathrm{Hal}$ ini bermakna bahwa segala bentuk aktivitas dan kegiatan yang diselenggarakan dan dilakukan didasarkan pada aturan hukum. Pada perkembangan ilmu tentang negara hukum maka terbagi menjadi dua kelompok negara hukum yaitu, negara hukum formal dan negara hukum materiil. Negara hukum materiil inilah yang

5 Ibid.

6 Dokumen Asesmen Badan Penanggulangan Bencana Daerah (BPBD) Kabupaten Ponorogo Tahun 2018.

7 Soemardi, Teori Umum Hukum dan Negara: Dasar-Dasar Ilmu Hukum Normatif sebagai Ilmu Hukum Deskriptif-Empirik, Bandung: Bee Media Indonesia, 2010, hlm. 225.

Dinda Riskanita, Upaya Pemerintah Daerah Mengatasi Kerusakan Lingkungan Akibat Alih Fungsi Lahan Berdasarkan Konsep Negara Kesejahteraan. 
Supremasi Hukum : Jurnal Penelitian Hukum

p-ISSN: 1693-766X ; e-ISSN: 2579-4663, Vol. 28, No. 2, Agustus 2019, 123-134

disebut negara negara kesejahteraan (Welfare State). Vilhem Lundsted berpendapat bahwa untuk mencapai negara yang sejahtera dari segi tatanan sosialnya adalah perlunya mendorong masyarakat yang hidup dalam satu tingkatan peradaban tertentu untuk mencapi cita-cita hidup masyarakat itu sendiri. ${ }^{8}$ Menurut Wilhem Lunstedt mengenai social welfare memiliki persamaan dengan apa yang dikemukakan oleh Roscou Pound, namun Vilhem Lundsted lebih menekankan mengenai keinginan terbesar manusia yaitu perkembangan hidup untuk kehidupan selanjutnya yang lebih layak. ${ }^{9}$

Melalui pandangan social welfare yang dikemukakan oleh Wilhem Lundsted tersebut dapat ditarik kesimpulan bahawa kesejahteraan sosial yang layak itu mencakup adanya jaminan keamanan sehingga disini hukum dapat berperan penting sebagai pengatur ketertiban yang harus didasarkan pada poin-poin dan skala-skala tertentu akan tetapi tetap memperhatikan kepentingan-kepentingan masyarakat yang bersifat dinamis. Hakikatnya negara kesejahteraan harus menempatkan diri untuk memberikan rasa aman, ketentraman dan kesejahteraan pada masyarakatnya agar tidak terjatuh pada kesengsaraan. Dalam konteks ini negara adalah alat utama sebagai bentuk untuk perwujudan kesejahteraan social.

\section{Lingkungan Hidup}

Lingkungan hidup adalah suatu wadah bagi manusia atau mahkluk hidup lain untuk hidup, tinggal, melakukan segala bentuk aktivitas dan melakukan interaksi, dimana dari interaksi tersebut akan memunculkan hubungan timbal balik dengan keberadaan makhluk hidup yang menempatinya, terutama manusia yang memiliki peran nyata dalam satuan kehidupan. ${ }^{10}$ Dapat dikatakan lingkungan adalah suatu media dari seluruh makhluk hidup hidup dan tinggal serta melakukan segala bentuk kehidupan yang akan menimbulkan hubungan timbal balik.

Komponen Lingkungan terdiri dari dua faktor, yaitu faktor abiotik dan faktor biotik. Faktor abiotik dapat berupa tanah, air, udara, cuaca dan suhu, sedangkan untuk faktor biotik berupa manusia, hewan dan tumbuhan. Dari dua komponen ini memunculkan dua jenis lingkungan, yaitu lingkungan alam dan lingkungan buatan. Lingkungan alam adalah lingkungan ciptaan Tuhan berupa sungai, laut. Lingkungan buatan manusia berupa taman kota, jalan, dan jembatan. Manusia sebagai pencipta lingkungan buatan yang bertindak secara social untuk memanfaatkan alam dan lingkungan untuk meningkatkan kesejahteraan hidup mempunyai pengaruh penting dalam kelangsungan ekosistem.

8Ibid, hlm. 9.

9 Ibid.

10 A. Rusdina, Membumikan Etika Lingkungan Bagi Upaya Membudayakan Pengelolaan Lingkungan yang Bertanggungjawab, ISSN 1979-8911, Vol IX No 2, 2015, p.. 247.

Dinda Riskanita, Upaya Pemerintah Daerah Mengatasi Kerusakan Lingkungan Akibat Alih Fungsi Lahan Berdasarkan Konsep Negara Kesejahteraan. 
Supremasi Hukum : Jurnal Penelitian Hukum

p-ISSN: 1693-766X ; e-ISSN: 2579-4663, Vol. 28, No. 2, Agustus 2019, 123-134

\section{Kerusakan Lingkungan}

Kerusakan lingkungan akan selalu dibarengi dengan tercemarnya suatu lingkungan. Kerusakan lingkungan sendiri adalah bentuk tindakan yang dilakukan oleh manusia yang menimbulkan perubahan fisik, hilangnya karakteristik baik secara langsung maupun tidak langsung terhadap sifat yang dimiliki, sehingga terlampauinya kriteria baku mutu kerusakan lingkungan hidup. ${ }^{11}$

Rusaknya suatu kondisi lingkungan memiliki makna bahwa menurunnya tingkat kegunaan untuk pemanfaatam tertentu bahkan bisa tidak digunakan sama sekali. Faktor yang menyebabkan rusaknya lingkungan ini disebabkan oleh dua hal, yaitu manusia dan alam.

Kerusakan lingkungan bisa menimbulkan suatu bencana seperti longsor, banjir. Hal ini terjadi karena adanya alih fungsi lahan yang berakibat pada rusaknya lingkungan, yang dimana tidak dilakukannya upaya reboisasi atau revegetasi. Perusakan lingkungan apabila dilihat dari peristiwa terjadinya, yaitu: ${ }^{12}$ (a) Disebabkan oleh alam atau perbuatan manusia; (b) Disebabkan oleh pencemaran, baik air, udara maupun tanah.

\section{Dampak Kerusakan Lingkungan Akibat Alih Fungsi Lahan Perbukitan Menjadi Lahan Perkebunan}

Berdasarkan Peraturan Bupati Kabupaten Ponorogo Nomor 24 Tahun 2013 tentang Rencana Kerja Pemerintah Daerah, aspek geografis Kecamatan Pulung terletak di ketinggian lebih dari 843 mdpl, sehingga cocok untuk pembukaan lahan perbukitan dengan jenis tanaman berakar tunggang untuk menampung debit air saat hujan, karena curah hujan di wilayah ini tinggi dengan intensitas deras. Dalam Peraturan Bupati Kabupaten tersebut tersebut, kawasan Desa Banaran yang menjadi obyek penelitian adalah desa yang seluruhnya lahan perbukitan yang berupa lereng dengan tingkat kemiringan lereng mulai dari $2 \%$ sampai dengan $>140 \%$. Titik lokasi penelitian berada di wilayah dengan tingkat kemiringan lereng 70-140\% (sangat Curam) yang tepat berada di kaki Pegunungan Wilis dan berada tepat di lereng Gunung Api Liman, dengan lahan terluas berupa hutan dengan kerapatan primer tinggi.

Peta Rencana Tutupan Lahan yang tercantum dalam Peraturan Daerah Kabupaten Ponorogo Nomor 1 Tahun 2012 tentang Rencana Tata Ruang Wilayah Kabupaten Ponorogo Tahun 2012-2032, tata guna lahan/tanah di tempat penelitian berupa kebun, belukar, sawah dan pemukiman. Lahan yang berada dilereng atas digunakan untuk lahan pohon pinus yang di tanam oleh Perhutani Provinsi Jawa Timur selaku pemilik lahan. Sedangkan lahan bagian lereng bagian tengah berupa perkebunan milik warga Desa Banaran yang ditanami dengan jenis tanaman berupa bambu, bawang

11 P. Joko Subagyo, Hukum Lingkungan (Masalah dan Penanggulangan), Jakarta:Rineka Cipta, 2002, hlm. 23.

12 Ibid.

Dinda Riskanita, Upaya Pemerintah Daerah Mengatasi Kerusakan Lingkungan Akibat Alih Fungsi Lahan Berdasarkan Konsep Negara Kesejahteraan. 
Supremasi Hukum : Jurnal Penelitian Hukum

p-ISSN: 1693-766X ; e-ISSN: 2579-4663, Vol. 28, No. 2, Agustus 2019, 123-134

merah dan jahe gajah. Dapat dilihat jika tanaman yang berada di lahan ini tidak sesuai dengan jenis tanah yang ada, sehingga menimbulkan rusaknya lingkungan dan hilangnya karakteristik lahan di kawasan perbukitan.

Dampak kerusakan terhadap lingkungan yang diakibatkan dari alih fungsi lahan perbukitan menjadi lahan perkebunan di Kabupaten Ponorogo khususnya Kecamatan Pulung adalah sebagai berikut:

1. Potensi terjadinya longsor secara terus menerus

Kecamatan Pulung yang berada di kaki Pegunungan Wilis yang kin sudah beralih fungsi menjadi lahan perkebunan ini sangat rentan mengalami bencana longsor.Hal ini dikarenakan jenis tanah yang ditanami di lahan ini tidak memiliki bebatuan seperti tanah dipegunungan. Longsor sering terjadi pada lahan tersebut pada saat kondisi musim kemarau, pada saat musim hujan terlebih lagi akan sangat berbahaya bagi masyarakat yang bertempat tinggal di kawasan lereng dan sekitarnya karena pada saat musim tersebut tingkat terjadinya longsor semakin meningkat. Meskipun demikian, lahan samapai sekarang masih menjadi tempat tinggal tetap masyarakat Desa Banaran. 2. Sulitnya mendapatkan air bersih

Desa Banaran yang sejatinya wilayah perbukitan, selalu mendapatkan akses mudah terkait air bersih untuk disalurkan ke berbagai desa lainnya, seperti Desa Bekiring.Karena terdapat tiga sumber mata air yang berada di Desa ini. Tetapi karena perubahan lahan yang terjadi sehingga menyebabkan longsor, maka berakibat juga pada terkuburnya sumber mata air tersebut sedalam 75 meter, sehingga memutus aliran air bersih.

Hal ini sangat dikhawatirkan masyarakat, karena air sebagai kebutuhan utama kehidupan sehari-hari seperti untuk makan dan minum. Sehingga masyakarat mengeluh ketika harus membeli air bersih.

3. Sulitnya melakukan reboisasi

Perbukitan yang sudah mengalami longsor akan menyebabkan tanah menjadi turun dan menjadi tanah datar, sehingga sulit untuk dilakukan reboisasi karena selain menyangkut jenis dan kontur tanah, tetapi juga menyangkut hak kepemilikan tanah. Tanah yang semula berada dibukit yang cocok ditanami dengan tanaman berakar tunggang, jika mengalami longsor akan menjadi jenih tanah yang tidak rapat atau terlepas. Hal ini yang menyebabkan kerusakan lingkungan menjadi semakin parah dan juga menurunkan produktivitas serta kesejahteraan masyarakat.

4. Hilangnya karakteristik lahan

Alih fungsi lahan yang tidak mengindahkan peraturan dana tata ruang memiliki resiko untuk menyebabkan kerusakan berupa hilangnya karakteristik lahan. Lahan yang sudah kehilangan karakteristik akan lebih mudah mengalami kerusakan yang berdampak pada lingkungan baik jangka pendek, menengah maupun jangka panjang. Akibatnya dengan curah hujan yang tinggi di Desa Banaran akan membuat tanah menjadi jenuh atau kondisi dimana pori-pori tanah sudah tidak mampu lagi menampung

Dinda Riskanita, Upaya Pemerintah Daerah Mengatasi Kerusakan Lingkungan Akibat Alih Fungsi Lahan Berdasarkan Konsep Negara Kesejahteraan. 
Supremasi Hukum : Jurnal Penelitian Hukum

p-ISSN: 1693-766X ; e-ISSN: 2579-4663, Vol. 28, No. 2, Agustus 2019, 123-134

air, sehingga sangat mudah mengalami longsor. Hal ini yang akan membahayakan bagi lingkungan desa sekitarnya.

5. Upaya pengembalian fungsi lahan yang sulit dilakukan

Penggunaan lahan yang tidak sesuai dengan peruntukkannya, hanya akan membawa masalah serius bagi lingkungan. Lahan yang sudah mengalami longsoran akibat alih fungsi akan sulit dilakukan upaya pengembalian ciri fisik lahan menjadi seperti semula.Sulitnya mengembalikan fungsi lahan akan menjadikan daerah tersebut tidak layak untuk dijadikan sebagai daerah/ladang produktif seperti perkebunan, atau daerah aman pemukiman, Sehingga penetapan kawasan rawan bencana pada daerah tersebut saat ini sudah dilakukan.

\section{Upaya Pemerintah Daerah Kabupaten Ponorogo dalam Mengatasi Kerusakan Lingkungan Berdasarkan Konsep Negara Kesejahteraan}

Pemerintah Daerah Kabupaten Ponorogo pada kasus terjadinya alih fungsi lahan di Desa Banaran, kemudian melakukan upaya-upaya penyelamatan lingkungan dan penyelamatan keberlangsungan hidup masyarakat daerah tersebut. ${ }^{13}$ Upaya yang dilakukan adalah dengan mengeluarkan Peraturan Daerah Nomor 1 Tahun 2012 tentang Rencana Tata Ruang dan Wilayah Kabupaten Ponorogo Tahun 2012-2032. Pada perda tersebut jelas mengatur tentang penataan ruang, misalnya penataan ruang untuk kawasan budidaya hortikultura seperti pertanian/perkebunan.

Dengan dikeluarkannya peraturan tersebut maka dapat dilihat bahwa kebijakan Pemerintah Daerah Kabupaten Ponorogo tidak hanya mengedepankan aspek lingkungan tetapi aspek keberlangsungan kehidupan masyarakat juga diperhatikan. ${ }^{14}$ Pertimbangan Pemerintah Daerah tersebut jika dikaji dengan konsep Negara Kesejahteraan, maka pemerintah daerah telah menerapkan konsep tersebut.

Pada perencanaan jangka panjang kedepan Pemerintah Daerah Kabupaten Ponorogo melalui Peraturan Daerah Nomor 1 Tahun 2012 tentang Rencana Tata Ruang dan Wilayah Kabupaten Ponorogo Tahun 2012-2032, jika disesuaikan dengan teori yang dibangun Vilhem Lundsted, menurut penulis dapat dijelaskan sebagai berikut:

1. Pemanfaatan dan Pengendalian Tata Ruang

Penggunaan lahan yang sesuai dengan peruntukkannya adalah tantangan tersendiri di masa yang akan datang untuk mengatasi krisis tata ruang yang telah terjadi

13 Muhammad Fajar Pramono, Setiawan Lahuri dan Mohammad Ghozali, Penerapan Manajemen Krisis dalam Pengelolaan Bencana Longsor Banaran, Pulung, Ponorogo, Khadimul Ummah Journal of Social Dedication, Vol. 1 No. 1, 2017, p. 12

14 Bayu Susena, Tesis, Pengendalian Pemanfaatan Tata Ruang Untuk Pendirian Bangunan Dalam Perspektif Pembangunan Berkelanjutan di Kabupaten Sleman, Yogyakarta, UMY, 2019, hlm. 72

Dinda Riskanita, Upaya Pemerintah Daerah Mengatasi Kerusakan Lingkungan Akibat Alih Fungsi Lahan Berdasarkan Konsep Negara Kesejahteraan. 
Supremasi Hukum : Jurnal Penelitian Hukum

p-ISSN: 1693-766X ; e-ISSN: 2579-4663, Vol. 28, No. 2, Agustus 2019, 123-134

seperti di Kecamatan Pulung. Diperlukan penataan ruang yang baik dan berada dalam satu sistem yang menjamin konsistensi dengan metode:

a) Arahan lokasi kegiatan yang tidak menimbulkan kerusakan lingkungan sehingga tetap didasarkan pada pengelolaan dan perlindungan lingkungan.

b) Batasan kemampuan lahan yang didalamnya termasuk daya dukung lingkungan dan kerentanan terhadap bencana alam.

c) Efisiensi dan sinkronisasi pemanfaatan ruang dalam rangka penyelenggaraan berbagai kegiatan.

2. Pengurangan Kesenjangan Pembangunan Antar Wilayah

Sama halnya dengan konsep Welfare State Vilhem Lundsted mengenai pandangan social welfare, upaya mengatasi kerusakan dengan pembangunan antar wilayah yang berjangka panjang, bertujuan untuk kehidupan yang layak untuk meningkatkan kesejahteraan masyarakat, bukan hanya untuk memeratakan pembangunan fisik tetapi juga untuk mengurangi kesenjangan kualitas hidup dan kualitas masyarakat itu sendiri. Perlunya perhatian dari pemerintah daerah terkait menekan resiko kerusakan lingkungan secara mendasar dan berkelanjutan akibat alih fungsi lahan yang terjadi agar tidak berujung pada kesengsaraan. ${ }^{15}$

Upaya yang dilakukan pemerintah daerah dari hasil penelitian yg kemudian diolah berdasarkan Konsep Negara Kesejahteraan maka untuk memenuhi rasa aman, nyaman, sejahtera bagi masyarakat yang terdampak kerusakan lingkungan akibat alih fungsi lahan adalah sebagai berikut:

1. Perencanaan tata guna lahan dan tata ruang

Perencanaan penatagunaan tanah dan lahan, khususnya dilakukan di wilayah perbukitan atau dataran tinggi seperti di Kecamatan Pulung yang merupakan bagian dari kegiatan penataan ruang Pemerintah Daerah Kabupaten Ponorogo, karena tanah merupakan bagian dari ruang yang sangat penting. Dalam perencanaan dan pelaksanaannya pun harus mengacu pada tata ruang wilayah, tata ruang wilayah Nasional, tata ruang wilayah Provinsi, dan tata ruang wilayah Kabupaten/Kota serta berprospek jangka panjang untuk kemakmuran dan kesejahteraan masyarakat. ${ }^{16}$

2. Penetapan metode penanaman bersilang atau tumpangsari

Lahan perbukitan yang tersisa sekarang hanya tertinggal tanaman pinus yang memiliki akar tunggang. Untuk sisa lahan yang berdampak longsor, pemerintah daerah bekerja sama dengan PERHUTANI dan Dinas Pertanian menerapkan metode penanaman

15 Bayu Susena dan Yeni Widowaty, 2018, Konsep Pengendalian Tata Ruang Sesuai Asas Pembangunan Berkelanjutan di Kabupaten Sleman, Prosiding Konferensi Nasional ke 7 Asosiasi Program Pascasarjana Perguruan Tinggi Muhammadiyah Aisyiyah (APPPTMA), hlm. 32

16 Arba, Hukum Tata Ruang dan Tata Guna Tanah Prinsip-Prinsip Hukum Perencanaan Penataan Ruang dan Penatagunaan Tanah, Jakarta: Sinar Grafika, 2017, hlm. 84.

Dinda Riskanita, Upaya Pemerintah Daerah Mengatasi Kerusakan Lingkungan Akibat Alih Fungsi Lahan Berdasarkan Konsep Negara Kesejahteraan. 
Supremasi Hukum : Jurnal Penelitian Hukum

p-ISSN: 1693-766X ; e-ISSN: 2579-4663, Vol. 28, No. 2, Agustus 2019, 123-134

tumpangsari dengan jenis tanaman pohon sengon dan mangga. Akan tetapi pemerintah tidak serta merta menjadikan lahan keseluruhan untuk tanaman berakar tunggang, tetapi masih mengedepankan dan mempertahankan aspek kesejahteraan masyarakat dengan cara mempertahankan tanaman jahe dan bawa merah sebagai ladang perekonomian masyarakat.

3. Melakukan penanaman ulang secara terus menerus

Terkait tata guna lahan yang tidak berdampak langsung terhadap longsor, Pemerintah Daerah Kabupaten Ponorogo bekerjasama dengan PERHUTANI Provinsi Jawa Timur telah melakukan upaya penanaman pohon pinus diwilayah lereng secara terus menerus dan bertahap di bagian atas. Hal ini bertujuan untuk meminimalisir semakin parahnya kerusakan lingkungan, dan mengoptimalkan kesejahtaraan sosial serta mencakup jaminan keamanan masyarakat. ${ }^{17}$

4. Penyuluhan lingkungan

Untuk menambah wawasan masyarakat terkait pentingnya lingkungan hutan di daerah Desa Banaran, Pemerintah Daerah Kabupaten Ponorogo mengutus BPBD Kabupaten Ponorogo secara rutin melakukan penyuluhan terkait lingkungan. Penyuluhan lingkungan dilakukan agar masyarakat sekitar lebih sadar dan peka terkait hal negatif dan positif lingkungan, tetapi tidak mengesampingkan perekonomian mereka dalam berkebun.

Adapun hal-hal yang disampaikan dalam penyuluhan antara lain:

a) Membangun kesadaran masyarakat terkait lingkungan melalui penanaman jenis tanaman yang harus ditanam di wilayah perbukitan Desa Banaran, seperti Sengon, Mangga dan Pinus.

b) Metode tanam silang di perkebunan milik pribadi. Karena masyarakat dahulu hanya menanam jahe sebagai tanaman utama, kini harus diselingi juga dengan tanamanan mangga. Hal ini dilakukan agar kesejahteraan masyarakat berlangsung lama, sehingga kehidupan dalam berlingkungan layak dan mencapai kesejahteraan social sebagai perwujudan Negara Kesejahteraan.

c) Penyampaian kepada masyarakat agar mematuhi aturan hokum terkait tata guna lahan agar sesuai dengan peruntukkannya sesuai dengan peraturan perundangundangan yang berlaku. Seperti Undang-Undang Nomor 26 Tahun 2007 tentang Penataan Ruang, Undang-Undang Nomor 32 Tahun 2009 tentang Perlindungan dan Pengelolaan Lingkungan Hidup, Undang-Undang Nomor 39 Tahun 2014 Tentang Perkebunan, dan Peraturan Daerah Kabupaten Ponorogo Nomor 1 Tahun 2012 tentang Rencana Tata Ruang dan Wilayah.

17Teguh Prasetyo dkk, Hukum dan Undang-Undang Perkebunan, Bandung: Nusa Media, 2013, hlm. 99.

Dinda Riskanita, Upaya Pemerintah Daerah Mengatasi Kerusakan Lingkungan Akibat Alih Fungsi Lahan Berdasarkan Konsep Negara Kesejahteraan. 
Supremasi Hukum : Jurnal Penelitian Hukum

p-ISSN: 1693-766X ; e-ISSN: 2579-4663, Vol. 28, No. 2, Agustus 2019, 123-134

\section{PENUTUP \\ Simpulan}

Dampak yang ditimbulkan akibat alih fungsi lahan yang terjadi di Kabupaten Ponorogo adalah potensi terjadinya longsor secara kontinu, sulitnya mendapatkan air bersih, reboisasi yang sulit dilakukan, hilangnya karakteristik lahan dan upaya pemulihan lahan yang mustahil dilakukan karena mengingat kawasan sudah menjadi lahan datar. Sehingga lahan tersebut ditetapkan menjadi Kawasan Rawan Bencana (KRB), yang dalam arti lain tidak layak dijadikan ladang produktivitas dan tempat tinggal. Terkait upaya Pemerintah Daerah Kabupaten Ponorogo mengatasi kerusakan lingkungan berdasarkan konsep Negara Kesejahteraan, sudah dilakukan dengan baik. Dengan melalui beberapa upaya, yaitu perencanaan tata guna ruang dan tata guna lahan, penetapan metode tanam silang (tumpangsari), melakukan penanaman ulang sesuai dengan karakteristik lahan secara terus menerus, dan penyuluhan lingkungan kepada masyarakat. Hal ini dilakukan untuk meminimalisir terjadinya kerusakan lingkungan yang berujung pada munculnya bencana alam dan juga sebagai wujud komitmen pemerintah daerah untuk mensejahterakan masyarakatnya dari segi pembangunan, ekonomi dan sosial tetapi tidak mengesampingkan keberlangsungan lingkungan guna terciptanya hubungan yang harmonis antara masyarakat dan lingkungan hidup.

\section{Saran}

Dari kesimpulan yang sudah dipaparkan di atas, maka perlu disampaikan rekomendasi yang berkaitan dengan hasil penelitian, yaitu, terkait bencana longsor yang terjadi sehingga berakibat pada rusaknya lingkungan karena alih fungsi lahan, maka perlu dilakukan pengelolaan yang memadai melalui lembaga khusus/tim penataan yang menangani kegiatan pertanian dan pemberlakuan zonasi pengelolaan lahan di wilayah Desa Banaran, Kecamatan Pulung. Meningkatkan koordinasi dengan berbagai pihak dalam hal pengawasan dan pengelolaaan kawasan agar lebih efektif dan optimal sehingga pemda dapat mengabil kebiajakan-kebijakan strategis dalam permasalahan ini. Pihak-pihak yang dimaksud antara lain adalah Dinas Lingkungan Hidup, Dinas Pertanian, Akademisi/universitas di bidang Lingkungan Hidup dan Hukum Sumber Daya Alam, Akademisi/universitas pada bidang ilmu Geografi atau ilmu Tanah, dan Wahana Lingkungan Hidup (LSM).

\section{DAFTAR PUSTAKA}

Akbar, Faisal, 2003. Dimensi Hukum dalam Pemerintahan Daerah, Medan: Pustaka Bangsa Press, Cet. 1.

Arba, 2017, Hukum Tata Ruang dan Tata Guna Tanah Prinsip-Prinsip Hukum Perencanaan Penataan Ruang dan Penatagunaan Tanah, Jakarta: Sinar Grafika.

Dinda Riskanita, Upaya Pemerintah Daerah Mengatasi Kerusakan Lingkungan Akibat Alih Fungsi Lahan Berdasarkan Konsep Negara Kesejahteraan. 
Supremasi Hukum : Jurnal Penelitian Hukum

p-ISSN: 1693-766X ; e-ISSN: 2579-4663, Vol. 28, No. 2, Agustus 2019, 123-134

Christie, Yosef Anata, dkk., 2013, Dampak Kerusakan Lingkungan Akibat Aktivitas Pembangunan Perumahan (Studi Kasus di Perumahan Palaran City oleh PT Kusuma Hady Property), Jurnal Beraja Niti, ISSN 2337-4608, V.2(11).

Dokumen Asesmen Badan Penanggulangan Bencana Daerah (BPBD) Kabupaten Ponorogo Tahun 2018.

Kabupaten Ponorogo, 2012, Peraturan Daerah Kabupaten Ponorogo Nomor 1 Tahun 2012 tentang Rencana Tata Ruang dan Wilayah Kabupaten Ponorogo tahun 2012-2032, Lembaran Daerah Kabupaten Ponorogo Tahun 2012 No. 2, Sekretariat Daerah, Ponorogo.

Kabupaten Ponorogo, 2012, Peraturan Bupati Nomor 24 Tahun 2013 tentang Rencana Kerja Pemerintah Daerah, Berita Daerah Kabupaten Ponorogo Tahun 2012 No. 6, Sekretariat Daerah, Ponorogo.

Pramono, Muhammad Fajar, dkk., 2017, Penerapan Manajemen Krisis dalam Pengelolaan Bencana Longsor Banaran, Pulung, Ponorogo, Khadimul Ummah Journal of Social Dedication, Vol. 1 (1).

Prasetyo, Teguh dkk, 2013, Hukum dan Undang-Undang Perkebunan, Bandung: Nusa Media.

Riskanita, Dinda, 2019. Tesis: "Kerusakan Lingkungan Akibat Alih Fungsi Lahan Perbukitan Menjadi Lahan Perkebunan di Kabupaten Ponorogo (Studi Kebijakan Formulasi Hukum)", Yogyakarta, UMY.

Rusdina, 2015, Membumikan Etika Lingkungan Bagi Upaya Membudayakan Pengelolaan Lingkungan yang Bertanggungjawab, ISSN 1979-8911, Vol IX No 2.

Republik Indonesia, 2007, Undang-Undang No. 26 Tahun 2007 tentang Penataan Ruang, Lembaran Negara RI Tahun 2007 No. 68, Sekretariat Negara, Jakarta.

Soemardi, 2010, Teori Umum Hukum dan Negara: Dasar-Dasar Ilmu Hukum Normatif sebagai Ilmu Hukum Deskriptif-Empirik, Bandung: Bee Media Indonesia, 2010.

Susena, Bayu dan Yeni Widowaty, 2018, Konsep Pengendalian Tata Ruang Sesuai Asas Pembangunan Berkelanjutan di Kabupaten Sleman, Prosiding Konferensi Nasional ke 7 Asosiasi Program Pascasarjana Perguruan Tinggi Muhammadiyah Aisyiyah (APPPTMA).

Dinda Riskanita, Upaya Pemerintah Daerah Mengatasi Kerusakan Lingkungan Akibat Alih Fungsi Lahan Berdasarkan Konsep Negara Kesejahteraan. 
Supremasi Hukum : Jurnal Penelitian Hukum

p-ISSN: 1693-766X ; e-ISSN: 2579-4663, Vol. 28, No. 2, Agustus 2019, 123-134

Susena, Bayu, 2019. Tesis: "Pengendalian Pemanfaatan Tata Ruang Untuk Pendirian Bangunan Dalam Perspektif Pembangunan Berkelanjutan di Kabupaten Sleman", Yogyakarta, UMY.

Subagyo, P. Joko, 2002. Hukum Lingkungan (Masalah dan Penanggulangan), Jakarta: Rineka Cipta.

Uar, Netty Dahlah, dkk., 2016. Kerusakan Lingkungan Akibat Aktivitas Manusia pada Ekosistem Terumbu Karang, Jurnal MGI, ISSN 0215-1790, V.30(1).

Dinda Riskanita, Upaya Pemerintah Daerah Mengatasi Kerusakan Lingkungan Akibat Alih Fungsi Lahan Berdasarkan Konsep Negara Kesejahteraan. 